\title{
KNOWLEDGE CO-PRODUCTION ON LANDSCAPE CHARACTERS, VISIONS AND PLANNING: THE CASE OF THE REGIONAL LANDSCAPE PLAN IN FRIULI VENEZIA GIULIA (ITALY)
}

\author{
Andrea GUARAN \\ University of Udine, ITALY \\ Department of Languages and Literatures, Communication, Education and Society - DILL \\ andrea.guaran@uniud.it
}

\section{Enrico MICHELUTTI}

University of Edinburgh, UNITED KINGDOM

Edinburgh School of Architecture and Landscape Architecture, ESALA

enrico.michelutti@uniud.it

DOI: http://doi.org/10.23740/TID120183

\section{ABSTRACT}

The recent debate on landscape planning in Europe has seen growing interest in knowledge co-production processes. The need to apply the European Landscape Convention and political pressures to pool the knowledge of citizens and non-experts has been at the fore in the last few regional landscape planning experiences in Italy. Using a qualitative approach and specific analysis criteria, the research examines the case of the Friuli Venezia Giulia Regional Landscape Plan (PPR FVG), exploring the relational geographies and the power relations embedded in the knowledge coproduction processes related to the Plan. This research provides a comprehensive map of the top-down and bottomup relations linking the actors producing knowledge on the regional landscape and an in-depth analysis on power equilibria for the key nodes structuring the landscape Plan. The study questions the knowledge co-production mechanisms included in a regional planning experience and stresses the importance of the exercise of co-production experiences in fostering the diffusion of "landscape democracy" at the micro-scale. Eventually, this research shows the complexity of relational dynamics, with links which are often unequal, but generally aimed at joint production of knowledge in relation to regional landscapes.

Keywords: knowledge co-production, landscape planning, Regional Landscape Plan of Friuli Venezia Giulia (Italy), relational dynamics among actors

\section{INTRODUCTION}

In Europe, the recent planning experiences on landscape at local and regional scales and the construction of strategies for the conservation and valorisation of the so-called "landscape goods" have shown the need for shared knowledge co-production of landscape characters, visions and the future. The limits of top-down approaches in landscape planning and the political willingness of involving community and non-expert knowledge in planning processes have been (at least formally) included in current European policy-making on landscape. This more collective approach to landscape perceptions and landscape planning, already recognized by the European Landscape Convention - ELC (Council of Europe, 2000), and within the ELC, mainly related to official forms of landscape planning (Jones, 2016; Vik, 2017), is not just a political compromise with the different stakeholders playing at the local/regional scale or a pro forma exercise for 
local groups of interest. It is deeply embedded in the (local) balance of power, which shapes the current policies on landscape and determines the interplay of interests in relation to landscape. Thus, knowledge on landscape becomes a real political issue and the production of knowledge in relation to local landscapes takes on a role which is not only limited to the academic debate but it deeply underpins the ideas of democracy and society that governments and political parties are developing on the territory.

Analysing the mechanisms, which inform the strategic choices in landscape planning, and examining the social production of landscape visions among the different actors involved in a local and regional planning experience, the research explores knowledge co-production dynamics in the case of the Regional Landscape Plan of Friuli Venezia Giulia (PPR FVG, Italy). This paper investigates the relational geographies in place among the different actors in a process of knowledge co-production on landscape and illustrates the complex web of power relations, which shape the nature and the results of the planning experience.

\section{KNOWLEDGE CO-PRODUCTION ON LANDSCAPE AND SOCIAL PRODUCTION OF LANDSCAPE: AN OVERVIEW}

The interest for knowledge co-production in landscape research is consolidated in literature within a trans-disciplinary frame (Enengel et al., 2012). While several theorists have questioned knowledge production and proposed types of knowledge categorizations (focussing on the use of knowledge, Pohl \& Hirsch Hadorn, 2007; on the dimensions of knowledge, Raymond et al., 2010; on the relation among different approaches to knowledge, Smith \& Jenkins, 2015), the debate has been extended to knowledge co-production mechanisms, the interrelations between impact and actor (Rossi et al., 2017; Cunliff \& Scaratti, 2017; McCabe et al., 2016), and the role and "generative value" of landscape in knowledge co-production, which have not been consolidated in literature yet. In fact, some authors have approached knowledge co-production on landscape through cross-disciplinary $(\mathrm{Wu}, 2006)$ or collaborative research (van Paassen et al., 2007), but the role of landscape in shaping specific co-production mechanisms among the different actors involved in knowledge processes on landscape remains a field open to further research (Shaw et al., 2017).

Due to our interest in examining the processes of knowledge co-production in relation to landscape, we approach the topic referring to the theories of landscape social production. On the one hand, the landscape is the subjective interpretation of the territorial reality, conceived as the result of a perceptive process, which filters the "real" data and is determined by the priorities and values of each person. Knowledge here is understood as a common patrimony of the subjects who build and relate with everyday reality (Berger \& Luckmann, 1966). It can be argued with the principle of the constructivist paradigm for which knowledge is the result of an active, individual and social construction, generally of an intentional nature.

On the other hand, society and its dynamics can be comprehensible "in terms of an ongoing dialectical process composed of the three moments of externalization, objectivization and internalization" (Berger \& Luckmann, 1966, p. 149). In this sense, the landscape, more precisely the subjective and objective factors that characterize it, can be traced back to the dynamism of the three stages enunciated by the two sociologists, which in this study concerns the perception and meaning of landscapes.

Thus, we can argue that, considering design as a manifestation of common knowledge, processes of collective construction of knowledge are effectively activated around the general 
category "landscape" and follow a "community" and "collective" project (which can be very diverse and contradictory, but remain possible and desirable in our perspective). Thus, the aim of this work is precisely to understand how and with what dynamics, in the examined case study, this overall project on the local and regional landscape has been concretized. In particular, the various relationships between the different actors involved in the planning process are examined, seeking to disassemble the production processes of collective knowledge.

THE CASE OF THE REGIONAL LANDSCAPE PLAN IN FRIULI VENEZIA GIULIA (PPR FVG): METHODOLOGY, FINDINGS AND ANALYSIS OF THE RELATIONAL GEOGRAPHIES

\section{Methodology}

The research methodology is built on qualitative methods both in data collection and analysis. The data collection includes almost fifty reports coming from local municipalities, other official documentations of Regional Landscape Plan and some materials included in semi-structured interviews involving the facilitators of the participatory process. The research analysis is based on qualitative methods and uses two criteria to explore the Plan relational geographies: the first concerns the functional dimension of each actor in relation to the Plan, understood as the main result of a co-production process elaborating local cultures and identities, imaginative visions and actual projects for the regional landscape; the second criterion deals with the dimension of power in relational geographies among the actors who took part in the more extended processes of knowledge co-production on regional landscapes produced by the Plan elaboration.

\section{Findings and analysis of the relational geographies}

The case study is based on the knowledge co-production related to the ideation, definition and elaboration of the Regional Landscape Plan in Friuli Venezia Giulia ${ }^{1}$. The structure of the PPR $\mathrm{FVG}^{2}$, based on the legal framework of Italian Law on Landscape, the Codice dei Beni Culturali e del Paesaggio (Code of Cultural Heritage and Landscape) drawn in continuity with the European Landscape Convention, has promoted functional relationships in relation to the collective construction of knowledge. The plan is structured in three parts: a) The normative part, defining the "landscape goods" under protection, and zoning the territory of the Region in sub-areas (defined as "landscape ambits"), which implement specific policies of conservation and promotion of landscape, according to the national legislation; b) The strategic part, building a multidimensional strategy, embedded in three networks (dealing with Heritage, Ecology and Soft Mobility) and four guidelines (addressing Land Consumption, Landscape and Environmental Assessment of Infrastructures, Localization and Design of Energy Infrastructures and Sustainable Tourism); c) The managing part, dealing with the implementation of the normative and strategic parts, with the monitoring activities in relation to landscape transformations and with the

\footnotetext{
${ }^{1}$ Referring to the Legislative Decree of $22^{\text {nd }}$ of January 2004, No. 42, all Italian Regional Administrations are required to adopt a Regional Landscape Plan, in order to protect and promote "landscape goods".

${ }^{2}$ According to the national normative frame, in 2013, the Friuli Venezia Giulia Regional Administration has started the process for the definition of the Regional Landscape Plan (Regional Law 14, 11 October 2013, modification of the Regional Law 5, 23 February 2007, following the National Legislative Decree 42, 22 January 2004, related to the article 10 of the National Law 137, 6 July 2002).
} 
creation of "landscape observatories" to integrate the tools of the Regional Landscape Plan with the other policies involving the territory.

The first key co-constructive relationship related to the PPR FVG involves the co-planning process between the Regional Administration and the central government (Ministry of Heritage, Cultural Activities and Tourism). This key relationship, required by law, operates through the PPR FVG Technical Committee. We begin by identifying the actors and their role, understanding the characteristics of the relational circuits between them, the hierarchical levels, the information flows and the reticular complexity embedded in the Plan.

The reconstruction of the dynamics between the different actors involved in the Plan is linked to the choices in terms of categorization and typology definition. This reconstruction cannot be developed without considering that we have played a specific role in the process. In fact, this experience is intended as an activity of direct observation lasting almost three years (the time of the Plan elaboration), working closely with different stakeholders, immerged in the dynamics generated by the actors involved by the Plan and, to a certain extent, as far as our part of the Plan elaboration was concerned, influenced by the relations which these dynamics brought to the Plan working group. We worked in close collaboration with the technical bodies of the Regional Administration and other independent (private) experts but, at the same time, with the group's Plan participatory activities, all the while involved in a complex web of relations with local communities (mediators ${ }^{3}$, local politicians, etc.).

Our main task in this research concerns the need to take a "step back", to look at the Plan as a "distant object", understood as the result of a knowledge co-production process in relation to the landscapes of Friuli Venezia Giulia but also as a living "map of relations" that can help us to explore the cultural and power substrata generating the Plan.

The relational geographies embedded in the Plan are a complex fabric, merging different typologies of relations in knowledge co-production. Three main categories of actors had a proactive role within the Plan:

- Public institutions producing and promoting knowledge on landscape with the main objective of setting up the Regional Landscape Plan (mainly the Regional Administration; the different levels of the Ministry of Heritage, Cultural Activities and Tourism; the municipal administrations, especially those that have signed an agreement to be part of the Plan participatory process with the Regional Administration);

- The university(ies) as promoter of knowledge and research on landscape, playing as a consultant for public institutions and mediator between public institutions and community, through the participatory process included in the Plan;

- Professionals and individual experts, contracted by public authorities to make available specific knowledge in relation to pre-defined fields and disciplines necessary to the Plan elaboration.

Other actors have been key subjects of the process mainly through the participatory process ${ }^{4}$ promoted within the framework of the Plan:

${ }^{3}$ Understood here as experts that facilitate the participation of citizens to the Plan.

${ }^{4}$ The participatory process included in the Plan was activated to collect indications on the conditions and perspectives of the different landscapes that characterize the territory under control of the Regional Administration. The process was structured on two levels: a local one, developed through community workshops and involving schools, aimed at the inhabitants of the municipalities who had signed an agreement with the Regional Administration; a regional one, through a WebGIS tool (called "Participatory Archive of Online Reports"), accessible to all citizens. 
- Local and regional stakeholders belonging to different sectors of society, including political parties, professional boards, eco-museums, NGOs, and local committees;

- Individual citizens and communities;

- Primary and middle school students (from ages 9 to 14).

During the elaboration of the Plan, the relation among actors in term of knowledge coproduction was different and very discontinuous in relation to frequency, intensity and role for the Plan. While a limited number of relations were set-up a priori (mainly by the Regional Administration), with a precise layout (or even a contract) defining the nature of the interactions (and the related production of knowledge), several relations took on a specific shape due to political decisions, technical needs or incidental factors. But within this maze of relations, we can identify two main groups of dynamics:

- A structured top-down dynamic (Figure 1), led by the Regional Administration, which shapes the knowledge production finalized for the elaboration of the Plan (with the consultancy of Udine University), investing resources in contracting external experts but also enhancing a "political project" including a contribution from other political institutions (e.g. municipalities);

- A more fluid bottom-up dynamic (Figure 2) based on a participatory process, promoted by the Regional Administration and coordinated by Udine University, where communities and other stakeholders of civil society have room in the knowledge co-production process with a very wide range of institutional solutions in place.

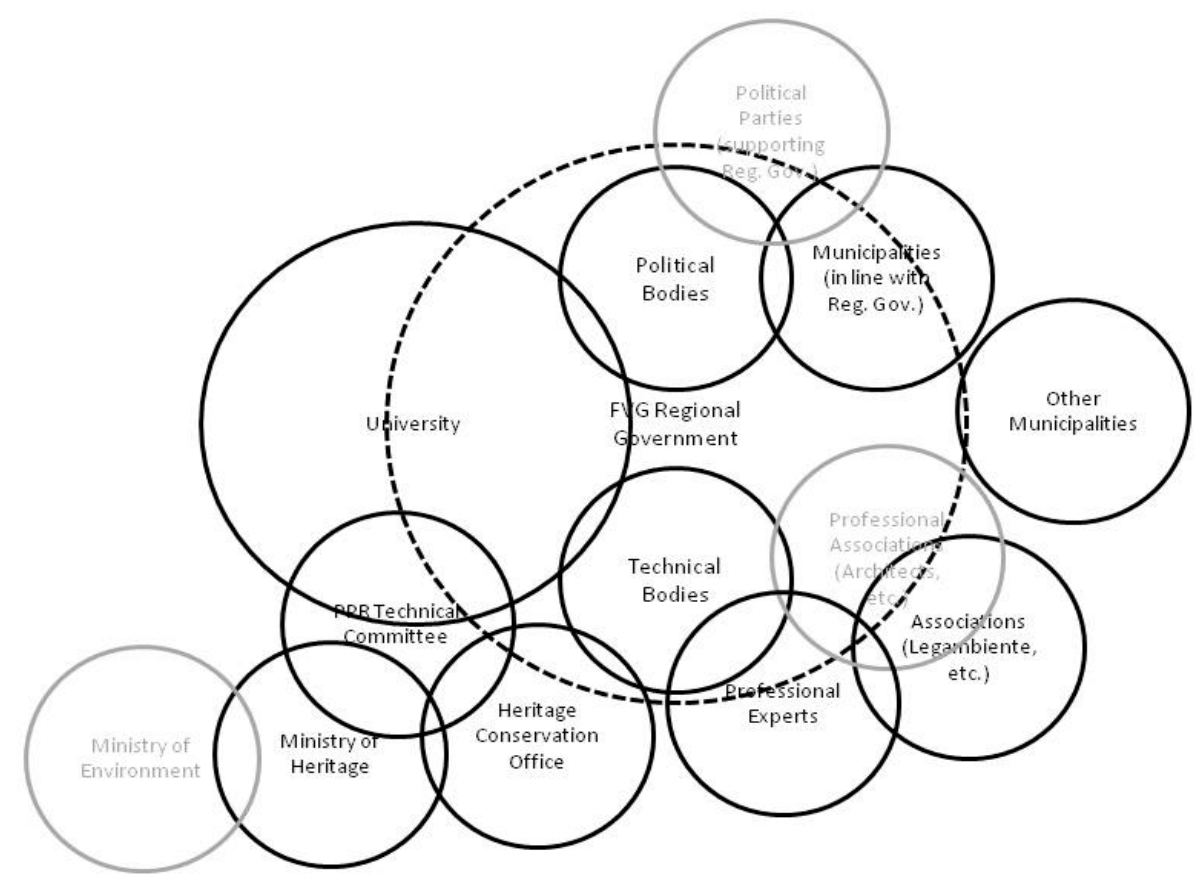

Figure 1: Top-down dynamics in knowledge co-production in relation to the Regional Landscape Plan of Friuli Venezia Giulia (in black, main actors; in grey, secondary actors; the dashed line shows the macro-category of the regional government)

Looking at the relations among actors, the role of the Regional Administration and that of the University (Table 1) as key nodes in knowledge co-production processes appears both in terms 
of promoting specific relations and being mediators among actors (who usually work independently, or are even in contrast with each other). The "drivers" behind the composition of these actors lie in the institutional set-up of the Plan, structured by the Regional Administration (Bertolini \& Pascolini, 2016). These two main actors, through a more informal and discontinuous fabric of relations, took part in the process of providing the knowledge coproduction of the Plan.

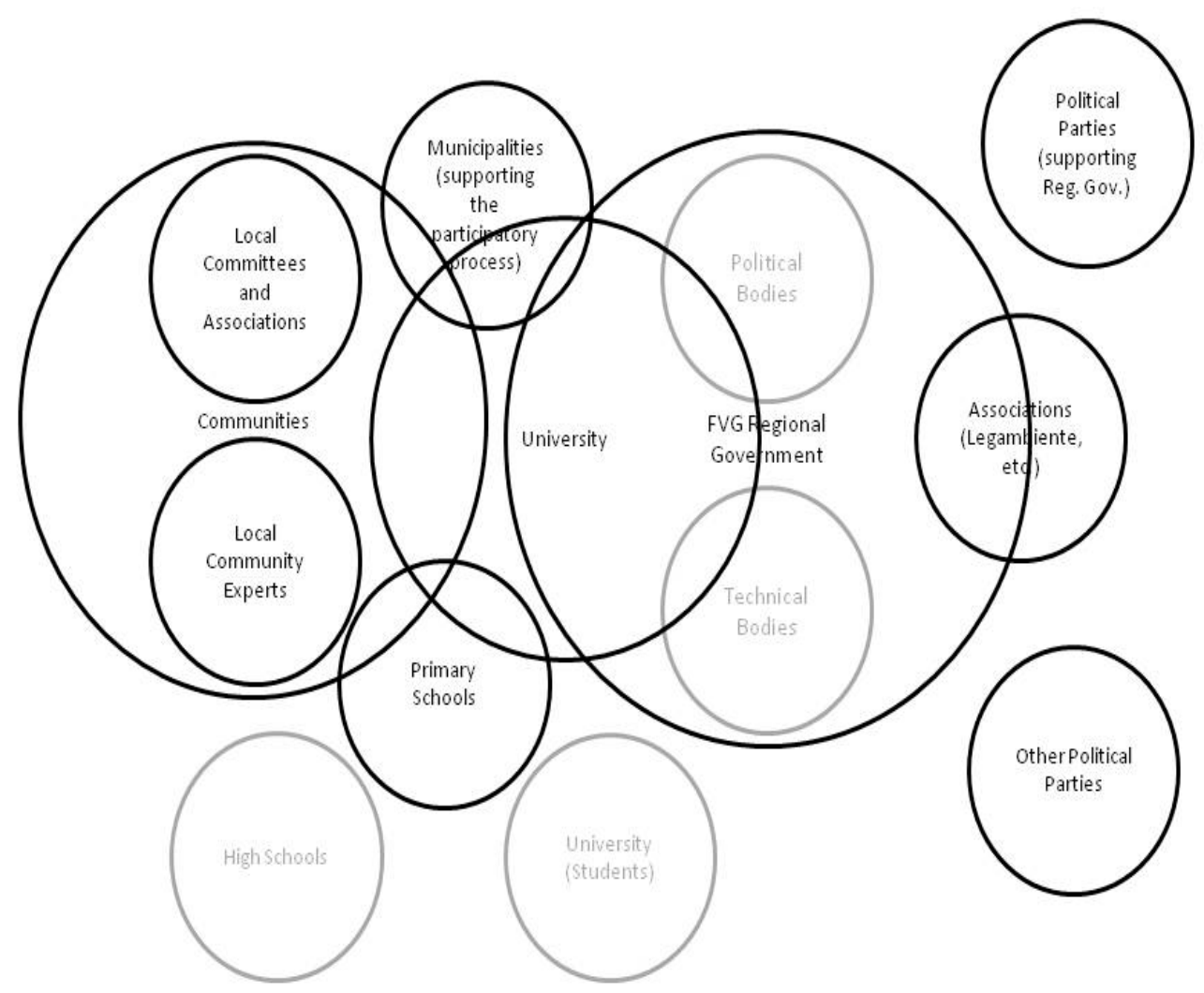

Figure 2: Bottom-up dynamics in knowledge co-production in relation to the Regional Landscape Plan of Friuli Venezia Giulia (in black, main actors; in grey, secondary actors)

Table 1 provides a first quantitative identification of the actors' network, but a further qualitative approach is required to achieve research objectives. Following the two top-down and bottom-up dynamics embedded in the co-production processes of the Plan (Figures 1 and 2), the analysis explores key relations in the PPR FVG elaboration, working in two conceptual fields and with analytical criteria: relational geographies and power balances. The two criteria are applied on four key nodes (Regional Administration (RA)-Ministry of Cultural Heritage; RAUniversity; RA-Municipalities; the "multiple" nodes relate to the participatory process developed in the Plan). The first examined relation involves the Regional Administration and the Ministry of Cultural Heritage and Activities. The two actors have worked together in the elaboration of the statutory part of the Plan, outlining the framework of the Plan and defining the actors' contexts of knowledge production in relation to the regional landscapes. The Regional Administration and the Ministry boards played a key role in controlling Plan elaboration activities and results, at different scales and in different stages. The Ministry has carried out a final activity of control, expressing the most recent legal and technical orientation on the issues 
discussed, particularly in the validation of landscape "assets" ${ }^{5}$ and protected areas. In addition to this role of control, both actors also had a decisive proactive role.

The Regional Administration directly shaped the legal part of the Plan and, in relation to the statutory part, provided the definition of landscape assets and protected areas (e.g. UNESCO sites and "symbolic centres" protected for their specific cultural value); it also played a significant role in the strategic part of the Plan, liaising with the University of Udine and related research groups. On the other hand, besides the step-by-step control and validation of the Plan, the Ministry fostered strategic comparisons with other experiences of regional landscape planning at the national level.

Table 1: FVG Regional Landscape Plan process: main actors and relations

\begin{tabular}{|c|c|c|c|c|c|c|c|c|c|c|c|c|}
\hline & $\begin{array}{l}\text { Commu- } \\
\text { nities }\end{array}$ & $\begin{array}{l}\text { FVG } \\
\text { Regional } \\
\text { Government } \\
\text { (political } \\
\text { bodies) }\end{array}$ & $\begin{array}{l}\text { FVG } \\
\text { Regional } \\
\text { Government } \\
\text { (technical } \\
\text { bodies) }\end{array}$ & $\begin{array}{l}\text { Local } \\
\text { Commu- } \\
\text { nity } \\
\text { Experts }\end{array}$ & $\begin{array}{l}\text { Local } \\
\text { Commi- } \\
\text { ttees and } \\
\text { Associati } \\
\text { ons }\end{array}$ & $\begin{array}{l}\text { Ministry } \\
\text { of } \\
\text { Heritage }\end{array}$ & $\begin{array}{l}\text { Munici- } \\
\text { palities }\end{array}$ & $\begin{array}{l}\text { PPR } \\
\text { Technical } \\
\text { Committee }\end{array}$ & 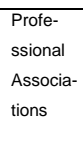 & $\begin{array}{l}\text { Regional } \\
\text { Heritage } \\
\text { Conser- } \\
\text { vation } \\
\text { Office }\end{array}$ & $\begin{array}{l}\text { Stu- } \\
\text { dents }\end{array}$ & $\begin{array}{l}\text { Uni- } \\
\text { versity }\end{array}$ \\
\hline Communities & & & & $x$ & $x$ & & $x$ & & & & $\mathrm{X}$ & $\mathrm{x}$ \\
\hline $\begin{array}{l}\text { FVG } \\
\text { Regional } \\
\text { Government } \\
\text { (political } \\
\text { bodies) }\end{array}$ & & & $x$ & & & $x$ & $\mathrm{x}$ & $x$ & & $x$ & & $\mathrm{x}$ \\
\hline $\begin{array}{l}\text { FVG } \\
\text { Regional } \\
\text { Government } \\
\text { (technical } \\
\text { bodies) }\end{array}$ & & $\mathrm{x}$ & & & $x$ & $x$ & $\mathrm{x}$ & $\mathrm{x}$ & $\mathrm{x}$ & $x$ & & $x$ \\
\hline $\begin{array}{l}\text { Local } \\
\text { Community } \\
\text { Experts }\end{array}$ & $x$ & & & & $x$ & & $\mathrm{x}$ & & & & $\mathrm{x}$ & $x$ \\
\hline $\begin{array}{l}\text { Local } \\
\text { Committees } \\
\text { and } \\
\text { Associations }\end{array}$ & $x$ & & $x$ & $\mathrm{x}$ & & & $x$ & & & & & $x$ \\
\hline $\begin{array}{l}\text { Ministry of } \\
\text { Heritage }\end{array}$ & & $x$ & $x$ & & & & & $x$ & & $x$ & & \\
\hline $\begin{array}{l}\text { Municipalitie } \\
\text { s }\end{array}$ & $\mathrm{x}$ & $x$ & $\mathrm{x}$ & $x$ & $\mathrm{x}$ & & & & & & & $x$ \\
\hline $\begin{array}{l}\text { PPR } \\
\text { Technical } \\
\text { Committee }\end{array}$ & & $x$ & $x$ & & & & & & & $x$ & & $x$ \\
\hline $\begin{array}{l}\text { Professional } \\
\text { Associations }\end{array}$ & & $x$ & $x$ & & & & & & & & & \\
\hline $\begin{array}{l}\text { Regional } \\
\text { Heritage } \\
\text { Conservation } \\
\text { Office }\end{array}$ & & $x$ & $x$ & & & $x$ & & $\mathrm{x}$ & & & & \\
\hline Students & $\mathrm{x}$ & & & $x$ & & & & & & & & $\mathrm{x}$ \\
\hline University & $\mathrm{x}$ & $\bar{x}$ & $\bar{x}$ & $x$ & $\mathrm{x}$ & & $\bar{x}$ & $x$ & & & $\bar{x}$ & \\
\hline $\begin{array}{l}\text { Total } \\
\text { relations }\end{array}$ & 5 & 7 & 8 & 5 & 5 & 3 & 6 & 5 & 1 & 4 & 3 & 8 \\
\hline
\end{tabular}

${ }^{5}$ The category of assets could be considered either of "significant public interest" or with the label "further contexts", entailing specific kinds of protection (for an overview, cf. Bertolini \& Pascolini, 2016). 
The second key node under examination entails the relations between the Regional Administration and the University of Udine on the one hand and the Regional Administration and the professionals involved in the Plan on the other. The network between these actors was shaped by the Regional Administration through different typologies of contract (five successive agreements with the University; instead individuals resorting to individual project contracts for professionals). The different contractual position determined an "asymmetry" in the relations among these actors. While the different university working groups ${ }^{6}$ accompanied the regional technical board in the evolution of the planning strategies for the entire duration of the Plan elaboration, from the initial drafting of the objectives to its approval by the Regional Council ${ }^{7}$, the professionals, on the other hand, worked for limited time frames, responding to specific tasks (e.g. the elaboration of the single data sheets on the specific landscape protected areas).

Despite the condition of asymmetry due to the nature of the contracts, these actors played as "co-protagonist" in the Plan elaboration because of the autonomy through which they developed the tasks assigned to them by the Regional Administration. This autonomy in part affected a real co-production of knowledge on the regional landscapes. Regarding the professionals, the realization of the studies did not deviate from the standard rules of the relationship between public body commissioning the design and professionals who perform as required by contract. An absence of dialogue characterized their relationship with the Regional Administration, impeding an actual deepening of the diverse themes embedded in the Plan. The lack of dialogue between these two actors also included the possibility of renegotiating the initial tasks fixed by the contract. On the contrary, the university working groups developed a process of constant renegotiation with the Regional Administration (including project assumptions, objectives, methodologies and applicative tools), fostering opportunity for collective reflection and real co-construction of cognitive paths on regional landscapes ${ }^{8}$.

A third key relation concerns the Regional Administration and the Municipalities. Municipalities chose to be part of an inter-municipal agreement and to activate the paths of participation on their territory and this choice defined the relationship between the two actors, and between the same municipalities (being part or not of the agreement, physically contiguous or included in the same "landscape ambit" from a territorial perspective). Part of the Municipalities (46\% of the total number of Friuli Venezia Giulia municipalities) had a closer relation with the Regional Administration, contributing to strengthen the knowledge on the landscape heritage of the territories which are under the auspices of the different local authorities. Moreover, on a strictly technical level, the Regional Administration and all the Municipalities, set up a system of data exchange, especially geo-references, useful to the elaboration of the Plan and to the preparation of the urban planning local instruments to be (drawn up according to the Plan recommendations).

${ }^{6}$ University Research groups were both mono-disciplinary (e.g. for the elaboration of the "Regional Ecological Network") and interdisciplinary (e.g. for the outlining "Guidelines for Sustainable Tourism").

${ }^{7}$ Under Italian law, the Regional Landscape Plans must be approved in two phases by the Regional Government: the first, called "adoption", launches the so-called phase for the "observations", which can be done by private and public bodies, associations and individuals; the second, defined "approval", follows the acceptance or refusal of the comments, which were received, and entails the approval of the Plan documents, including additions required in the "observation" phase.

${ }^{8}$ This approach, developed by the University, was useful also in relation to the normative-legal part of the Plan, which was elaborated mainly by the regional administration team, resulting in the so-called "Technical Standards for the Plan Implementation". 
A fourth significant node of the relational geographies in knowledge co-production processes concerns the participatory process embedded in the $\mathrm{Plan}^{9}$ : in fact, also regional civil society stakeholders (mainly representatives of environmental and professional associations) and citizens were "co-protagonist" in the Plan elaboration. The participatory process was carried out on two levels: a local one, addressing the citizens belonging to the Municipalities ${ }^{10}$ who had signed an agreement with the Regional Administration, developed through inter-municipal and municipal workshops and through the involvement of schools ${ }^{11}$; a regional one, built on a WebGIS tool ("Participatory Archive of Online Reports") accessible to all citizens, through which elements of value and degradation in the regional landscape were reported.

The two forms of participation and categories of participants (association representatives and citizens) were characterized by a discrepancy in terms of time. While the associations and professional bodies came into play only in the last few months of the Plan elaboration, mainly suggesting corrections to the Plan drafted documents, the local communities were asked to provide their contribution before outlining the Plan, being involved in the participatory process for some months in the initial phase of the Plan elaboration. The choices of the Regional Administration in terms of participation depended on the profile and the characteristics of the two actors and their potential impact on the Plan. The inclusion of professional associations and the citizens for the entire process, working closely and deciding the contents of the Plan, resulted as complex and not easily achievable for the Regional Administration. Due to the political choice of involving citizens in the process only to a certain extent, the process excluded intense and long-lasting participatory planning tools.

On the one hand, the Region Administration, framing the Plan from a legal perspective and supporting the agreements with the municipalities in terms of resources, enabled citizens to provide their readings on territorial characters, including them in a "collective" construction process of knowledge on the regional landscapes. On the other hand, the Region Administration limited the role of the population only in the initial stage of the Plan, excluding the citizens a priori from real participation during the entire process of the Plan elaboration. On the contrary the Regional Administration's choice of involving professional associations (architects, planners, surveyors, engineers, agronomists and forestry science experts), and agricultural and environmental associations (i.e. Legambiente) was in recognition to their position and contribution toward the final definition of the Plan outputs (in particular to implementing the technical standards schedules for the adaptation of municipal planning tools to the Landscape Plan) $)^{12}$.

The second criterion of analysis concerns the power relations embedded in the processes of coproduction of knowledge on the landscape triggered by the elaboration of the Plan. This meant investigating the position held by each actor in the web of the Plan relations, studying "dominance" and "dependence" behaviours in their nuances, degrees and evolutions during the

${ }^{9}$ Using as a legal and political reference the European Landscape Convention and the Code of Cultural Heritage and Landscape.

${ }^{10}$ The municipalities involved were 96 , with about 2,300 citizens who took part in moments of public confrontation.

${ }^{11}$ Fourth and fifth primary school grades and the three middle school grades were involved. Approximately 7,300 students were involved in the process, with more than 5,000 reports collected.

12 This fact finds confirmation in all the meetings organized (in a separate or collegial way) in the weeks immediately preceding and following the act of Adoption of the Landscape Plan (June and July 2017 and in the phase immediately preceding the presentation of the observations, in November 2017). 
knowledge co-production processes. This allows us to aggregate the actors in a different way, based on "supremacy" and "dependency", redesigning the relational geographies within the Plan.

An equal contribution to the Plan was provided by the relations between public institutions (Ministry of Heritage, Cultural Activities and Tourism and Regional Administration) in the framework of a co-planning experience. In fact, with different prerogatives and specific tasks, the whole process of the Plan was directed by these two actors. This position of shared dominance was maintained during the Plan elaboration although a strengthening of the role of the Regional Administration and a change in the tasks of the local offices of the Ministry led to a continuous reorganization of this co-management of the Plan.

Concerning the node Regional Administration-municipalities, there was a close relation between the regional technical direction and the municipal technical offices, allowing, for instance, the digitalization of specific protected areas in relation to the municipal plans. This translated into mutual cooperation, including a production of new knowledge on specific aspects, but in the context of a non-equal relationship, with a top-down relation where the Municipalities were asked to "perform" without holding an exchange of views on the conditions and forms of the performance. At the political level, power relations between the Regional Administration and municipalities also lacked balance. The municipal governing bodies were convened in general assemblies and informed about the progress of the Plan. Feedback was gathered without a real participatory process, which was impossible because of the schedule of meetings itself ${ }^{13}$.

The relation between the Regional Administration and the University was built on scientific cooperative agreements and therefore on an equal relationship. The nature of this relationship frequently took different shapes, with the predominance of the Regional Administration (technical components) in the decision-making process. University working groups have made an essential contribution working in synergy with regional experts, but sometimes undergoing strategic choices and timing. For instance, the process of community participation was based on one of the agreements signed between the Region Administration and the university. However, the university research groups had to face the choices made by the Regional Administration (relating to political opportunities and strict timetables), with limited margins of negotiation. The two actors collaborated on equal terms, with autonomy of choice, at least on certain parts of the Plan. In any case, the key strategic decisions, under the supervision of the Regional Administration, conditioned the relationship with the University, shifting it from a synergistic and concerted action to an unbalanced client-contractor one.

Concerning the power relations between the Regional Administration and the Professional Associations, the behaviour of the Regional Administration in relation to the Professionals Associations (allowing them the opportunity to validate the Plan in the delicate final phases, even though through an ex-post mechanism) confirm their leading role in the Regional Administration perspective and the influences that they can exercise in the web of regional political negotiations. In the final phase, close to the definitive approval on the $21^{\text {st }}$ of March 2018, the two actors assumed a decisive function, in which the logic of consensus took over. A potentially serious and synergistic contribution to knowledge and common planning had been transformed in part into a less edifying partnership due to power and based on the logic of consensus.

${ }^{13}$ The scheduled meetings took place on the following dates: $22^{\text {nd }}$ of June $2015,6^{\text {th }}$ of November 2015 , $17^{\text {th }}$ of May 2016, and $7^{\text {th }}$ of July 2016. 
The participatory process ${ }^{14}$ offered room for the collective production of knowledge, involving a significant number of citizens in the collection of data, ideas, evaluations and proposals regarding the conditions of the different local landscapes. Despite being part of the same legal framework, under the technical and organizational direction of the university, the participatory processes activated by the Regional Administration were not homogeneous. Some workshops addressing local knowledge co-production and systematization were characterized by the mutual cooperation among citizens. In other cases, the interference of local politicians, aiming to be an "active part" in the debate, influenced the workshops as well as the presence of the socalled "local experts" or planning professionals, who assumed a predominant or prominent position, assigned to them a priori by the citizens or gained during the work ${ }^{15}$.

A non-uniform relational dynamic involved also the participatory process "facilitators" 16 and the local administrators. This relation was characterized by a clear dependence of the "facilitators" in relation to the administrators (only in few cases allowing room for moderate autonomy), due to the contractual relationship in place between the two actors. Despite that, in some cases, the facilitators were able to ensure a real opportunity for the citizens' participation ${ }^{17}$ through the workshops in which their contribution was provided independently, free from pressures of any kind $^{18}$. A key additional factor was the concern regarding the participants' origin. For the community members, the involvement was generally linked to their attachment to the landscape values of their own territory; for non-members, what emerged was not only an interest in claiming local instances ${ }^{19}$, but similarly also the desire to shape the comparative activities between different areas, with principles and values not necessarily rooted in the single local context.

This diversity in the Plan's relational geographies is even more extended if time and space are considered as factors playing a role in knowledge co-production. In fact, despite the intention of covering the entire territory during the Plan elaboration and development (thus including the period after the Plan's final approval, in an operation to be implemented through landscape observatories), actors and stakeholders played (and play) their role in a scattered way in the territory during the different phases of the Plan ${ }^{20}$. Similarly, there was a clear geographical distinction in knowledge co-production fluxes: the top-down dynamics affected the entire territory of Friuli Venezia Giulia, while the bottom-up processes took place in a fragmented way. This led to a significant loss of knowledge on local landscapes, which remained hidden and/or unexpressed ${ }^{21}$.

${ }^{14}$ For a detailed analysis on the methods of engaging citizens and particularly in reference to their different landscape readings, refer to Guaran \& Carestiato (2018) and Bianchetti \& Guaran (2018).

${ }^{15}$ For a short introduction on bottom-up processes in the current social context, see Eberly, 2008.

16 The University organized a training course to guarantee to all facilitators a basic knowledge on participatory strategies, methods, and tools.

${ }^{17}$ The participatory workshops have clear guidelines and objectives to be achieved according to the needs of the University participatory working group.

18 In some cases, facilitators had to free the debate from the influences of the Mayor's opening discourse.

${ }^{19} \mathrm{E}$.g. the provincial referent of Legambiente, an environmental association, or Fiab, a regional association that supports cycling.

${ }^{20}$ Significant is the amount of online reports uploaded simultaneously with the numerous meetings to launch the participatory process and the immediate subsequent implementation of the comparison tables at a municipal level. Messages that rapidly diminished in the months when the spotlight on the enlarged participatory strategy to local communities was extinguished.

${ }^{21}$ In this regard, what is significant is the difference (in terms of number of online reports) between the municipalities which joined the participatory process (organizing meetings open to citizens and involving 


\section{CONCLUSIONS}

The analysis of relational geographies in the case of PPR FVG has shown the landscape plan as a conceptual space where a plurality of visions and interests come together, seeking a common terrain of dialogue. The case study has revealed different modalities of engagement for the actors and the influences that these types of relation (on an equal basis, asymmetric, etc.) and ways of structuring the relationship (by contract, by independent choice, on a voluntary basis, etc.) have in allowing an actual contribution of each actor to the knowledge co-production processes on landscape. In this context, which are the methodological instruments that can facilitate the dialogue between actors? How can a participatory approach offer real responses? To what extent and how can expert and non-expert sources of knowledge work together within a fixed political framework exercising landscape planning? These are some of the gaps in our 'tools box'. Having said that, we need to look deeper into knowledge co-production processes on landscape from a relational perspective.

The analysis of power relations in the PPR FVG has shown that landscape is the "political result" of the interplay between the powers controlling a certain territory. The "rules of the game" of a planning exercise makes the fight between different interests and needs even more evident. The case study has presented two contrasting dynamics: a top-down one, controlled by public institutions with a reduced margin of negotiation by the other actors involved in the process, which has produced the main part of the Plan; a bottom-up one, sustained and founded by the same public institutions, which has involved to a certain extent communities and civil society, having a limited impact on the Plan but fostering, through participatory activities, a capillary diffusion of knowledge co-production processes at the micro-scale. These experiences have given space to critical questioning of the Plan's top-down dynamics, but have also offered room for democratic debate on the institutions governing the territory and, in the best cases, the bases for a real re-appropriation of landscape by citizens. After our experience in the Plan elaboration several questions emerge: to what extent can academic and civil society institutions play an independent role in landscape planning, free from political engagements and conventional "pre-defined" positions? What are the instruments to avoid "landscape visions" imposed by established powers? What tools can be provided to enable communities to "truly" participate in high-scale planning experiences? Is it simply a legal issue? Or are other tools available to alter the power of balance in landscape planning, addressing "democratic landscapes"? Further research needs to be implemented to fill these gaps.

In terms of contribution to the knowledge co-production processes, professionals (in particular architects and planners contracted by the Regional Administration), have played a significant role, providing research and in-depth analyses of local landscape, although in a limited synergy with the other actors (mainly the Regional Administration and the University), consisting in few intermediate verifications of ongoing tasks ${ }^{22}$.

young students) and municipalities which did not sign agreements with the Regional Administration (quite a few reports were collected for an area covering half of the regional territory). More than $80 \%$ of the reports concern the municipal territories that signed an agreement with the Region.

${ }^{22}$ E.g. the case of the Tepco Company, contracted by the Regional Administration for producing the identification, description and mapping of the morphological types of landscape, so-called "urban and agro-rural morphotypes". 
In relation to the impact of the communities in the Plan elaboration ${ }^{23}$, input coming from the participatory process was included into the Plan, in particular in the studies concerning the twelve landscape areas in which the regional territory has been divided, and in the ecological, cultural heritage and soft mobility strategic networks. The community contribution, limited to consultation and data collection on local landscapes, refers to a partial subordination of the community in relation to the Regional Administration.

There remains the need to identify other criteria of analysis to understand characters and modes of social construction of knowledge in relation to landscape. Workshops at the municipal (or local) level constituted key moments of collective production of knowledge (in relation to landscape values and criticalities). Citizens ${ }^{24}$ have been able to provide examples of intergenerational and inter-professional dialogue, preparing cognitive elements surrounding local landscape conditions through direct experience.

The awareness gained by groups of citizens (though a minority), and their desire to provide a real contribution to landscape planning is evidence of an effective common process of knowledge production that the elaboration of the Regional Landscape Plan of Friuli Venezia Giulia has made possible and promoted. Although the experience cannot be entirely defined using the standards of democratic practice applied to the landscape, however the development of the Plan has proposed some interesting examples of knowledge co-production practices that might just reduce this gap.

\section{Note}

This contribution was conceived and developed jointly by the two authors, who also wrote together most of the texts; A. Guaran is responsible for the drafting of the Conclusions, E. Michelutti of the paragraph Knowledge Co-production on Landscape and Social Production of Landscape: An Overview.

\section{REFERENCES}

BERGER, P.L., \& LUCKMANN, T. (1966). The Social Construction of Reality. A Treatise in the Sociology of Knowledge, Garden City. NY: Anchor Books.

BERTOLINI, C., \& PASCOLINI, M. (2016). II Piano Paesaggistico Regionale del Friuli Venezia Giulia. Quaderno 1. La Struttura del Piano e la VAS, Udine.

BIANCHETTI, A., \& GUARAN, A. (2018). I processi partecipativi nell'esperienza del Piano Paesaggistico Regionale del Friuli Venezia Giulia. Geotema, forthcoming.

COUNCIL OF EUROPE (2000). European Landscape Convention, Florence.

CUNLIFFE, A.L., \& SCARATTI, G. (2017). Embedding Impact in Engaged Research: Developing Socially Useful Knowledge through Dialogical Sensemaking. British Journal of Management, 28(1), 29-44.

EBERLY, D. (2008). The Rise of Global Civil Society: Building Communities and Nations from the Bottom Up. New York: Encounter Books.

ENENGEL, B., MUHARB, A., PENKERC, M., FREYERD, B., DRLIKE, S., \& RITTER, S. (2012). Co-production of Knowledge in Transdisciplinary Doctoral Theses on Landscape Development. An Analysis of Actor Roles and Knowledge Types in Different Research Phases. Landscape and Urban Planning, 105, 106-117.

${ }^{23}$ The Regional Administration decided to involve the community through consultation, thus renouncing to activate any form of real participatory planning exercise (Manconi, 2015).

${ }^{24}$ Participants were mainly adults and elderly people, but in some cases the workshops involved significant groups of young people. 
GUARAN, A., \& CARESTIATO, N. (2018). La partecipazione nella pianificazione del paesaggio: significati e valenze. In SALVATORI, F. (ed.), L'apporto della geografia tra rivoluzioni e riforme, Atti del XXXII Congresso Geografico Italiano (Roma, 7-10 giugno 2017), forthcoming.

JONES, M. (2016). Landscape Democracy and Participation, in a European Perspective. In: K. JøRGENSEN, M. CLEMETSEN, K.H. THORÉN, \& T. RICHARDSON (eds.), Mainstreaming Landscape through the European Landscape Convention (pp. 119-139). London: Routledge.

MANCONI, L. (2015), Livelli della partecipazione, Roma, FormezPA. Retrieved 22 February 2018, from: fondistrutturali.formez.it/sites/all/files/livelli_partecipazione.pdf

MCCABE, A., PARKER, R., \& COX, S. (2016). The Ceiling to Coproduction in University-industry Research Collaboration. Higher Education Research and Development, 35(5), 1-15.

POHL, C., \& HIRSCH HADORN, G. (2007). Principles for Designing Transdisciplinary Research. Munich: Oekom Verlag, Gesellschaft für ökologische Kommunikation mbH.

RAYMOND, C. M., FAZEY, I., REED, M. S., STRINGER, L. C., ROBINSON, G. M., \& EVELY, A. C. (2010). Integrating Local and Scientific Knowledge for Environmental Management. Journal of Environmental Management, 91, 1766-1777.

ROSSI, F., ROSLI, A. \& YIP, N. (2017). Academic Engagement as Knowledge Co-Production and Implications for Impact: Evidence from Knowledge Transfer Partnerships. Journal of Business Research, 80, 1-9.

SHAW, B.J., DRAUX, H. GARCÍA MARTín, M. MARTIN, J., \& BIELING, C. (2017). Contributions of Citizen Science to Landscape Democracy: Potentials and Challenges of Current Approaches. Landscape Research, 42(8), 831-844.

SMITH, H., \& JENKINS, P. (2015). Trans-disciplinary Research and Strategic Urban Expansion Planning in a Context of Weak Institutional Capacity: Case Study of Huambo, Angola. Habitat International, 46, 244-251.

van PAASSEN, A., OPDAM, P., STEINGRÖVER, E., \& van den BERG, J. (2007). Landscape Science and Societal Action. Knowledge in Action, 285-302.

VIK, M.L. (2017). Self-mobilisation and Lived Landscape Democracy: Local Initiatives as Democratic Landscape Practices. Landscape Research, 42(4), 400-411.

WU, J. (2006). Landscape Ecology, Cross-disciplinarity, and Sustainability Science. Landscape Ecology, 21(1), 1-4. 